\title{
Electronic Rubrics Design to Assess Student Competence in Vocational Education
}

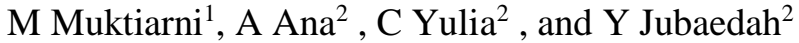 \\ ${ }^{1}$ Technology and Vocational Education Study Program, Post Graduate UPI \\ ${ }^{2}$ Home Economics Education, Faculty of Technology and Vocational Education UPI \\ muktiarni@upi.edu
}

Keywords: Electronic rubric, competence, food and beverage service.

Abstract: This research aimed at developing an instrument that contains a rubric on food and beverage service practice in vocational education that is valid, practical, and effective. Based on preliminary studies conducted on several universities, lecturers still using judgments with points or ratings without a clear criterion in the assessment of practical work. Such assessments tend to be subjective and inaccurate. One way to overcome this is to use the electronic rubric and practical guide for use by students. The method used a Design Based Research to model the development which consists of three stages are the preliminary stage, development stage, and implementation. The study was made up of a sample of food and beverage lecture and 30 Culinary Education student at Indonesia University of Education. In the development electronic rubric to obtain the material that is accordance with the expectations of research, the research scheme this time only to the stage of development. In the preliminary stage, literature analysis was conducted lecture and student Culinary Education needs analysis on the use of electronic rubrics in the sight of lab work. In the development stages the assessment was validated by experts, 2 experts matter and 1 expert assessment. Qualitative and quantitative data was collected through questionnaires, the data was descriptively analyzed. The results of the study consisted of instruments used in food and beverage service performance task of student assignments as a guide for students in carrying out lab work and performance assessment consisting of electronics rubric as practical competency guidelines. The results of the development were validated, based on expert discussions conducted using the Aiken index coefficient.

\section{INTRODUCTION}

This study is an assessment instrument development rubric electronic form on the practical implementation of food and beverage service. One evaluation tool that can be used in assessing the competence of students in vocational education is a performance assessment. Performance assessment can be carried out using an instrument task (task) and the rubric. Tasks may include individual and group assignments. Tasks are designed such appropriate subjects of interest, so that students can show ability or skill that becomes the purpose of scoring in subjects (B. Moskal, 2003). Rubric is the assessment criteria used as guidelines in conducting a performance assessment or the work of students (Karkehabadi, 2013; Brookhart, 2013; Lau, 2011).

Competence courses that must be achieved in the food and beverage service course pretty much, the process of practical lecturers have not yet standardized assessment tool. The process of evaluation of students' skills using observation sheet is still not effective in monitoring all students in the class element. Rate manually observation sheet is relatively difficult. Apart from having to write on a sheet, the data still must be transferred to the software to archive database. Another difficulty is that the observer had to memorize all the indicators were observed (Ochoa, et al., 2017). After the evaluation process, the lecturer does not have quantitative and qualitative data from all the assessment results, making it less efficient. Therefore, tools that are easy, practical, efficient, accurate, responsive required to perform qualitative and quantitative assessment using the rubric electronics.(Martínez, et al., 2012; Robles, et al., 2014), The use of electronics in skills assessment 
rubric can provide convenience and time efficiency in the assessment process (Eyal, 2012),

The purpose of this study is to identify and analysing the problems (needs assessment) faculty evaluation tools used in assessing the competence of student practicum in food and beverage service, and to generate electronic design rubric used in assessing the competence of students in vocational education. The use of the rubric will reduce the subjectivity of the lecturer in assessing skills and competencies of students (Allen, 2008). To support the necessary skills and competencies studentsproper assessment system. The assessment system that will encourage educators to teach better and students to learn better, or in other words to encourage improvement of the quality of learning (Guskey, 2003). Important principle that assessment is accurate, economical, and enhance the quality of learning.

electronic rubric (e-rubric) Have certain characteristics in the evaluation of learning outcomes assessment (product, project or task) and the level of performance or competence achieved by students (Raposo \& Martínez, 2011), Before giving assignments to the students, faculty inform students about the criteria that must be achieved by the students in accordance with the plan set out in the curriculum, the assessment process by using e-rubric can provide feedback to students (Mertler, 2001; Andrade \& Du, 2005), E-rubric can be used in a formative and summative evaluation and can distinguish between the assessment rubric and instructional rubric (Andrade \& Du, 2005; Andrade, 2014), Rubric electronic (e-rubric) provide greater interaction between students and professors, so that lecturers do not become autonomous in the process of evaluating the competence of students (Smith, 2016), The information provided in section votes electronically (e-rubric) in more detail, thus enabling teachers can identify the competencies that are difficult to achieve by students (Martínez, 2014),

\section{RESEARCH METHOD}

This research use approach DBR (Design-Based Research), the study was divided into three stages: 1) The preliminary consists of identification and analysis of problems, 2) development of prototype program, 3) test and prototype implementation of the program. Stages of research in this scheme up to the prototype development phase of the program, while the field trial stage and prototype implementation of the program planned for the next research scheme in the form of extensive trials which results will be published either in the seminar or journal. The subject of research as need assessment is 4 lecturer food and beverage service of the several different universities and 30 students of culinary education Indonesian Education University. At this stage of needs assessment activities that researchers do is to establish the basic problems encountered in the assessment used as an evaluation tool in the practical implementation, identifying the characteristics of assessment used by lecturers during practical implementation, reviewed the contents of assessment used and analyze student opinion regarding assessment tools used by lecturers currently practical implementation. In the prototype development stage researchers are beginning to define the concept of evaluation tools that will be made, to design an evaluation tool according to the indicators in the development of evaluation tools. The result of the development of the prototype were tested for validation by experts comprising of 2 specialist subject matter experts from the Lecturer, evaluation expert and practitioner Food and Beverage Service in the Tourism Academy. The data collection techniques in this study using interviews and questionnaires / questionnaire. The data analysis technique used is descriptive statistics.

\section{RESULT AND DISCUSSION}

This study uses the approach of Design-Based Research (DBR), that consist of three stages: Problem Identification and Analysis (Need Assessment), DevelopingPerformance Assessment (rubric) Based on Need Assessment and Validation Test performance task and Performance Assessment (Rubric). Results and discussion are translated according to the DBR stages, as follows:

\subsection{Identification Problem and Analysis (Need Assessment)}

\subsubsection{Need Assessment of Lecturer}

Needs analysis carried out to lecturer food and beverage service at several universities, with the aim to determine the understanding teachers about assessment rubric that have been implemented in food and beverage service learning on campus. At the time of analysis of the problem netted some information on the understanding of lecturers on assessment instruments used in the learning activities specifically on practical implementation of food and beverage service, as follows: 
Table 1. Results Analysis Lecturer Food and Beverage Service Course

\begin{tabular}{|c|c|c|}
\hline No. & $\begin{array}{l}\text { Components } \\
\text { Instruments }\end{array}$ & Result \\
\hline 1 & $\begin{array}{l}\text { An understanding of } \\
\text { the performance } \\
\text { assessment and } \\
\text { columns }\end{array}$ & $\begin{array}{l}\text { Lecturer see performance } \\
\text { assessment as an } \\
\text { assessment tool that is } \\
\text { used when the practical } \\
\text { implementation, while } \\
\text { sections are restrictions } \\
\text { or guidelines that are } \\
\text { used in the } \\
\text { implementation of } \\
\text { performance appraisal or } \\
\text { practices (performance) }\end{array}$ \\
\hline 2 & $\begin{array}{l}\text { Creation and } \\
\text { development of } \\
\text { performance } \\
\text { assessment }\end{array}$ & $\begin{array}{l}\text { Lecturers have never } \\
\text { made and apply the } \\
\text { scoring rubric }\end{array}$ \\
\hline 3 & $\begin{array}{l}\text { The implementation } \\
\text { of performance } \\
\text { assessment and } \\
\text { columns }\end{array}$ & $\begin{array}{l}\text { Lecturers have not } \\
\text { implemented } \\
\text { performance assessment } \\
\text { as a whole, regardless of } \\
\text { the process but just look } \\
\text { at the results. }\end{array}$ \\
\hline 4 & $\begin{array}{l}\text { Indicators of } \\
\text { performance } \\
\text { assessment } \\
\text { conducted }\end{array}$ & $\begin{array}{l}\text { Steps being taken by } \\
\text { food and beverage } \\
\text { service lecturer in } \\
\text { pacticum is planning, } \\
\text { implementation and } \\
\text { evaluation }\end{array}$ \\
\hline 5 & $\begin{array}{l}\text { Obstacles } \\
\text { encountered in the } \\
\text { manufacture, } \\
\text { development and } \\
\text { implementation of } \\
\text { performance } \\
\text { assessment and } \\
\text { columns in learning } \\
\text { activities food and } \\
\text { beverage service }\end{array}$ & $\begin{array}{l}\text { Constraints in designing, } \\
\text { developing and } \\
\text { implementing } \\
\text { performance assessment, } \\
\text { due to a lack of detailed } \\
\text { knowledge and } \\
\text { understanding of the } \\
\text { performance appraisal }\end{array}$ \\
\hline
\end{tabular}

It can be concluded from the findings of the analysis results of food and beverage service lecturer is professor has never been to create and apply an assessment rubric for practical implementation. Lecturers have not implemented performance assessment as a whole, regardless of the process but just look at the results. At the time of its application lab process progresses, the number of students tested need make effective assessment tool that can be used in the assessment process. The number of competencies to be assessed to make lecturers should be able to develop performance assessment with the assessment rubric further facilitate the practical assessment process. Performance assessment requires students to demonstrate the application of knowledge in a particular context (B. Moskal, 2003). Rubric is a scoring guide, which consists of the performance criteria previously set, which is used to evaluate the performance of students (B.Moskal, 2003). A rubric-based assessment criteria guide which consists of measuring equipment (4 points, 6 points, or appropriate) and a description of the characteristics for each value (Wiggins and McTighe, 2005).

The Analysis of Students for an Assessment Food and Beverage Service

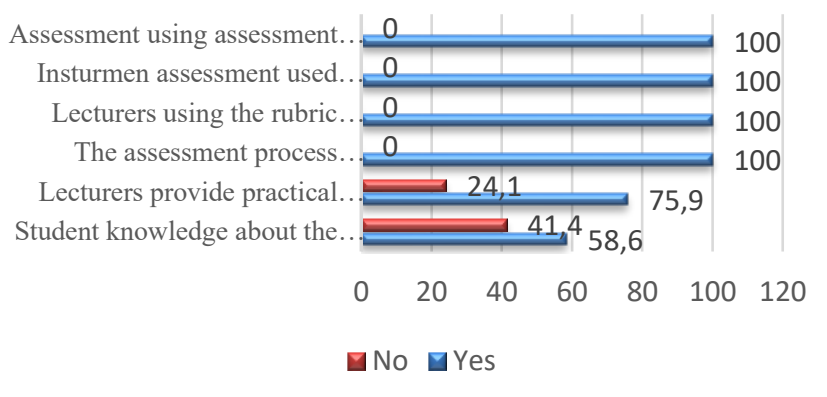

\subsubsection{Need Assessment of Students}

Needs analysis is done to the students who had contracted subjects in and Culinary Education student at Indonesia University of Education, with the aim to determine the student's understanding of the rubric assessment used in the learning food and beverage service lecturer at the university. The scope of students' understanding contained in the

instrument of research includes an understanding of the assessment tools used by lecturers, laboratory assessment rubric, electronic lab rubric in the assessment process.

Findings from analysis of students on assessment practicum course outline food and beverage service competence students do not know the assessment tools used by lecturers when lab, besides that students expect the assessment food and beverage service practicum courses done using assessment rubric, so students can improve the competence of weakness. Students are also asked to think about the use of electronic rubric in the assessment process, the results of assessments for all students agree with the use of instrument assessment of digital (electronic rubric), it is one of the efficient ways that can be used lecturer for practical assessment 
process, because the results of the assessment can be directly accessed by students and can give feedback to the students. Rubric assessment has two important aspects, namely the first assessment criteria are coherent and have a clear description of the performance criteria (Brookhart, 2013), Rubric good is a rubric that can be both descriptive evaluation tools and evaluative. Basically, rubric can be used as an evaluation tool, but the working principle is still offset performance with an overview of the assessment criteria that have been determined.

\subsection{Development Performance Assessment (rubric) Based on Need Assessment}

Performance development assessment (rubric) based on the identification and analysis of problems of the faculty and students. Researchers designed a performance assessment by following the general steps in the design and development of performance assessment. There are three basic steps in this process are: setting goals, choosing activities, and develop assessment criteria (Allen, 1996; Brualdi, 1998; Herman, Aschbacher., \& Winters, 1992; Moskal, 2003). Specify clear objectives; This stage determines the concepts, knowledge and skills in the subject of food and beverage service that will be accessed by students. The second stage is to determine the performance of the activity; some recommendations as a guide to define work activities, namely: (1) select a performance that will be accessed; (2) the completion of performance accompanied by an assessment of learning experience; (3) the purpose and objectivity of the accompanying performance assessment; (4) The assessment of performance should not be biased. The last stage is to develop assessment criteria (section); which is a guide for scoring. Sections should be clear and agreed learners and educators. Development of performance assessment competence food and beverage service refers to the ASEAN Common Competency Standards for Tourism Professionals Division 1-Hotel Services Restaurant Services listed in Hospitality SKKNI. Performance assessment can be carried out using an instrument task (task) and the rubric. Researchers designed the task performance as a guide that can be used by students in the practical implementation. Performance task or guiding sheet is a checklist of the steps that must be followed when operate or practice something (McTighe, 2015). Performance task used student when working on practical work or lab so that the learners more easily do what is done in accordance with the instructions that have been determined. Performance task developed by researchers adjusted for competency to be achieved by students according to curriculum design.

\subsection{Validation test performance task and Performance Assessment (rubric)}

Validation of performance task and performance assessment (rubric) conducted by three experts, consisting of two materials experts competent in the field of food and beverage service and an expert assessment. Data analysis was performed on each sheet validation of research instruments, the validator to write an assessment of each instrument with the criteria for states that every instrument is valid consisting of four (4) degrees of the scale of assessment that is not good (score 1); less good (score 2); either (value 3), and excellent (score 4). Results obtained from the experts then analysed based on the average score and refer to the determination of the level of validity interval instruments. Based on the above criteria then stated that the performance criteria for the task and performance assessment (rubric)Validated has a good degree of validation, if the minimum level of validation is achieved is a valid level. The validator gives an opinion that task performance can be used without revision while performance assessment (rubric) can be used with little revision on the part of scoring and has been fixed on the advice of the validator. Recapitulation of expert validation results can be seen in Table 3.1 and 3.2 below.

Table 2. Validation Results Performance Assessment

\begin{tabular}{|l|c|l|}
\hline \multicolumn{1}{|c|}{ Rated aspect } & $\begin{array}{c}\text { Average } \\
\text { Validation }\end{array}$ & $\begin{array}{c}\text { Level } \\
\text { Validation }\end{array}$ \\
\hline Aspects of user & 4 & $\begin{array}{l}\text { Can be used } \\
\text { without revision }\end{array}$ \\
\hline $\begin{array}{l}\text { Aspects of assessment } \\
\text { material / content }\end{array}$ & 4 & $\begin{array}{l}\text { Can be used } \\
\text { without revision }\end{array}$ \\
\hline aspects of language & 4 & $\begin{array}{l}\text { Can be used } \\
\text { without revision }\end{array}$ \\
\hline
\end{tabular}

Table 3. Validation Results Performance Task (rubric)

\begin{tabular}{|l|c|l|}
\hline \multicolumn{1}{|c|}{ Rated aspect } & $\begin{array}{c}\text { Average } \\
\text { Validation }\end{array}$ & \multicolumn{1}{|c|}{$\begin{array}{c}\text { Level } \\
\text { Validation }\end{array}$} \\
\hline Aspects of user & 4 & $\begin{array}{l}\text { Can be used without } \\
\text { revision }\end{array}$ \\
\hline Aspects of content & 3 & $\begin{array}{l}\text { Can be used with } \\
\text { little revision }\end{array}$ \\
\hline aspects of language & 4 & $\begin{array}{l}\text { Can be used without } \\
\text { revision }\end{array}$ \\
\hline
\end{tabular}


Based on statistical calculation results show that the performance of tasks and performance assessment (rubric) which have been developed can be widely tested and implemented in the implementation of competency assessment in Vocational Education.

\section{CONCLUSIONS}

Based on the results of research and development and discussion conducted in this study showed that the evaluation tool used by the lecturer in assessing student practicum raw yet, because it required the development of a valid evaluation tool, practical, and effective. Instrument development phase is done by carrying out the identification and analysis of problems (needs assessment) against lecturers and students. From the preliminary study produced a performance assessment as a practical assessment of competence food and beverage service and performance task to guide students in carrying out practical work. The test results demonstrate the validity of the criteria are adequate and meet the minimum standards specified in each test.

\section{REFERENCES}

Allen. (2008). Developing and Using Rubrics for Assessing, Grading, and Improving Student Learning. USA: SACS-COC Summer Institute.

Andrade, H., and Du, Y. (2005). Student Perspectives on Rubric-Referenced Assessment. Practical Assessment, Research \& Evaluation, 10(3), 1-12.

Brookhart, S.M. (2013). How to Create and Use Rubrics for Formative Assessment and Grading. Journal of Experimental Psychology: General, USA: ASCD.

Ochoa, H.M, Fuciños, R. and Domínguez, K. (2017). New implementation of Work Sampling Analysis for validating the Present Idle Time Indicator of Maintenance and Ship Repairing Business Line of Cotecmar.

Eyal, L., (2012). Digital Assessment Literacy: The Core Role of The Teacher in A Digital Environment Liat Eyal Learning Management Systems (LMS) benefits and limitations, 15, 37-49.

Guskcy, T.R. (2003). How Classroom Assessments Improve Learning. Educational Leadership, 60(5), 611.

Karkehabadi, S., and Ed, M. (2013). Using Rubrics to Measure and Enhance Student Performance. Virginia: Northern Virginia Community College.

Martínez-figueira, E., (2014). Electronic Rubrics to Assess Competences in ICT Subjects, 13(5), 584-594.
Mertler, C. a., (2001). Designing Scoring Rubrics for Your Classroom. Practical Assessment Research Evaluation, 7 (25), 1-10.

Moskal, B. M. (1995). Recommendations for Developing Classroom Performance Assessments and Scoring Rubrics - Practical Assessment, Research \& amp; Evaluation, 8 (14), 1-5.

Raposo, M., and Martínez, E., (2011). La Rúbrica en la Enseñanza Universitaria: Un Recurso Para la Tutoría de Grupos de Estudiantes. Formación Universitaria, 4 (4), 19-28.

Smith, J. S. (2016). Assessing Creativity: Creating a Rubric to Effectively Evaluate Mediated Digital Portfolios. Journalism and Mass Communication Educator, 72(1), 24-36.

Wiggins, G. and McTighe, J. (2005). Understanding by Design, Expanded 2nd Edition. Alexandria: ASCD. 